\title{
KAJIAN IDE KURIKULUM 2013 PAUD DAN IMPLIKASINYA DALAM PENGEMBANGAN KTSP
}

\author{
Prihantini $^{1}$
}

\begin{abstract}
ABSTRAK
Perubahan kurikulum merupakan bagian dari pengembangan kurikulum, karena perjalanan kurikulum selalu mengalami penyempurnaan maka disebut dengan pengembangan kurikulum. Sebagaimana lahirnya Kurikulum 2013 Pendidikan Anak Usia Dini juga merupakan perubahan kurikulum baru. Kebijakan yang ditetapkan bahwa Kurikulum Tingkat Satuan Pendidikan (KTSP) disusun oleh Satuan Pendidikan. Dalam penyusunannya satuan pendidikan perlu membentuk Tim Pengembang Kurikulum Tingkat Satuan Pendidikan. Untuk dapat mengembangkan KTSP, Tim Pengembang Kurikulum Tingkat Satuan Pendidikan perlu memahami ide Kurikulum 2013 PAUD, karena tampa memahami ide yang termuat didalamnya maka KTSP yang dikembangkan akan berbeda dan bukan merupakan kesinambungan dari ide Kurikulum 2013 PAUD. Dokumen yang disusun berbeda dengan ide yang sesungguhnya maka akan berdampak pula pada proses pembelajaran yang berbeda, karena implementasi pembelajaran bukan merupakan kesinambungan dari dokumen KTSP maupun ide Kurikulum 2013 PAUD.
\end{abstract}

Kata Kunci: Kurikulum 2013 PAUD, ide kurikulum, KTSP

\section{A. PENDAHULUAN}

Secara historis kurikulum di Indonesia telah mengalami beberapa kali perubahan. Perubahan kurikulum yang tercatat dalam sejarah (Hasan;2017) adalah perubahan kurikulum dalam enam periode, yakni 1946-1959, 1959-1965, 1966-1968, 1975-1994, 2004-2006, dan kurikulum 2013. Tanpa bermaksud membandingkan atau meninjau perubahan-perubahan kurikulum sebelumnya, kajian ini terfokus pada perubahan terakhir yakni Kurikulum 2013. Kebijakan dengan lahirnya kurikulum 2013 adalah dengan ketetapan bahwa kurikulum dikembangkan pada tingkat satuan pendidikan untuk semua jenjang, termasuk jenjang PAUD - Fenomena perubahan kurikulum lebih tepatnya dimaknai sebagai perbaikan atau penyempurnaan kurikulum sebelumnya, karena tidak mungkin suatu kurikulum dikembangkan untuk sepanjang zaman. Pengembangan kurikulum mempunyai makna yang cukup luas, dan dalam perjalanannya suatu kurikulum selalu mengalami proses penyempurnaan sehingga diberi nama pengembangan kurikulum (Sukmadinata dkk., 2006:19). Dengan demikian dapat dikatakan bahwa perubahan kurikulum merupakan bagian dari proses pengembangan kurikulum. Nasution (2011:3) mengatakan bahwa pengembangan kurikulum senantiasa harus dilakukan secara kontinu.

Pengembangan kurikulum adalah proses yang tak henti-hentinya, yang harus dilakukan secara kontinu. Jika tidak, maka kurikulum menjadi usang atau ketinggalan zaman. Makin cepat perubahan dalam masyarakat, makin sering diperlukan penyesuaian kurikulum.

Berlakunya kebijakan kurikulum 2013 untuk PAUD sebagaimana ditetapkan melalui Keputusan Mendikbud Nomor 146 Tahun 2014 tentang Kurikulum 2013 Pendidikan Anak Usia Dini. Seiring pemberlakuan kurikulum 2013 PAUD terbit sebelumnya Peraturan Mendikbud Nomor 137 Tahun 2014 yang mengatur tentang Standar Nasional PAUD. Kebijakan yang ada dalam dua peraturan perundangan tersebut berimplikasi pada

\footnotetext{
${ }^{1}$ Dosen Kampus UPI di Cibiru
} 
pengembangan Kurikulum Tingkat Satuan Pendidikan (KTSP PAUD) yang harus dikembangkan oleh tiap Satuan Pendidikan jenjang PAUD.

Dua peraturan tersebut pada dasarnya memuat ide tentang kurikulum 2013, sehingga keduanya seharusnya dipahami oleh tim pengembang KTSP jenjang PAUD. Sebagaimana dikemukakan oleh Hasan (2008:121) bahwa ide kurikulum merupakan komponen terpenting dalam proses pengembangan kurikulum. Lebih rinci pendapatnya adalah sebagai berikut.

Ide kurikulum adalah komponen terpenting dalam proses pengembangan kurikulum. Ide kurikulum merupakan rumusan dari posisi filosofis pendidikan yang dianut, pandangan teoritik tentang konsep kurikulum, model kurikulum yang digunakan, konsep tentang konten, organisasi kurikulum, desain kurikulum, desain dokumen kurikulum, posisi peserta didik dalam belajar. Ide kurikulum harus jelas karena ide tersebut menjadi dasar dan landasan bagi pengembangan berbagai komponen dokumen kurikulum.

Pendapat tersebut menunjukkan bahwa dalam pengembangan kurikulum ide kurikulum perlu dipahami oleh tim pengembang, sehingga pengembangan dokumen kurikulum yang disusun mencerminkan kesinambungan dengan ide kurikulum. Tanpa kejelasan ide kurikulum dimungkinkan terjadi ketidak sinambungan antara ide dan dokumen kuirkulum. Hasan (2008:123) mengatakan bahwa kejelasan ide kurikulum sangat membantu tim pengembang dalam mengkonstruksi dokumen kurikulum.

\section{B. PEMBAHASAN}

\section{Hakekat Kurikulum}

Secara hakiki, kurikulum adalah jantung suatu proses pendidikan (Klein, 1996 dan Oliva, 1997) dalam Hasan (2017:4), karena kurikulum adalah perangkat pendidikan yang secara langsung mewakili pendidikan dalam menjawab tantangan masyarakat (Oliva,1997) dalam Hasan (2017:4). Dalam hal ini kurikulum menduduki posisi penting dalam proses pendidikan karena kurikulum merupakan seperangkat rencana atau program pendidikan yang akan digunakan sebagai pedoman dalam penyelenggaraan proses pembelajaran untuk mencapai tujuan pendidikan. Posisi kurikulum sebagai komponen utama dan amat penting dalam penyelenggaraan pendidikan karena pada dasarnya adanya rancangan atau kurikulum formal dan tertulis merupakan ciri utama pendidikan di sekolah (Sukmadinata;1997:3). Dalam literatur lain (Sukmadinata dan Syaodih; 2012:31) mengemukakan bahwa kurikulum merupakan inti dari proses pendidikan, sebab diantara bidang-bidang pendidikan, kurikulumpengajaran merupakan bidang yang paling langsung berpengaruh terhadap hasil pendidikan. Pendapat lain yang mengatakan tentang posisi penting kurikulum dalam pendidikan yaitu Soedijarto dalam harian Kompas (2008:117) bahwa kurikulum memegang peran penting bagi pembangunan dan pembentukan sebuah karakter bangsa. Peran penting kurikulum dalam sistem pendidikan dikemukakan pula oleh AL Fandi (2011:220) bahwa tanpa kurikulum, suatu sistem pendidikan tidak dapat dikatakan sebagai sistem pendidikan yang sempurna. Alasan yang dikemukakan adalah bahwa kurikulum dalam sistem pendidikan merupakan ruh (spirit) yang menjadi gerak dinamik suatu sistem pendidikan. Kurikulum secara hakiki adalah jalan yang harus ditempuh peserta didik guna mencapai tujuan program pendidikan (Yamin; 2012:37), karena itu tanpa adanya kurikulum yang jelas maka tujuan pendidikan yang akan dicapai akan menjadi buyar. Braslavsky (www.ibe.unesco.org/2013/09/27) mengatakan bahwa "using educational concept, we can say that the curriculum defines the educational foundations and contents".

Pendapat-pendapat tersebut dapat dikatakan merupakan dasar pemikiran bahwa posisi kurikulum amatlah penting dan berperan sebagai kunci untuk mengarahkan pendidikan. 
Kurikulum memiliki peran kunci menurut Yamin(2012:15-16), bahwa kurikulum berkaitan erat dengan proses pembelajaran sebagai ruang beraktifitas belajar anak didik supaya mereka mendapat bekal pengetahuan yang baik dan mampu membangun kekuatan kecerdasan baik kognitif, afektif, dan psikomotor.

Membahas hakekat kurikulum maka akan ditemui berbagai konsep yang dikemukakan para ahli berdasarkan pandangannya. Beberapa konsep kurikulum oleh para ahli sebenarnya tidak semata-mata dipengaruhi oleh pandangan yang dimiliki tetapi pandangan tersebut juga dipengaruhi oleh perkembangan yang terjadi di masyarakat, baik perkembangan ilmu pengetahuan dan teknologi maupun perkembangan tuntutan masyarakat terhadap sekolah sebagai lembaga pendidikan.

Konsep kurikulum yang sudah lama dikenal adalah kurikulum sebagai sejumlah mata pelajaran atau ilmu pengetahuan yang harus ditempuh oleh peserta didik untuk mencapai suatu tingkat tertentu atau untuk memperoleh ijazah (Zais; 1976:7). Dalam pengertian ini, peserta didik dikatakan berhasil dan lulus sekolah apabila telah menguasai sejumlah mata pelajaran yang ada dalam kurikulum. Berangkat dari pengertian kurikulum sebagai sejumlah mata pelajaran maka proses pembelajaran pada satuan pendidikan, siswa diarahkan untuk menguasai isi mata pelajaran dan untuk mengetahui apakah siswa telah menguasai diadakan tes hasil belajar.

Perkembangan lebih lanjut seiring dengan perkembangan ilmu pengetahuan dan teknologi berdampak pada berbagai aspek kehidupan dan berdampak pula terhadap pergeseran fungsi sekolah sebagai institusi pendidikan. Sekolah tidak saja dituntut untuk dapat membekali sejumlah ilmu pengetahuan tetapi juga dituntut untuk mengembangkan minat dan bakat, membentuk moral kepribadian, dan dituntut pula agar peserta didik menguasai sejumlah keterampilan yang dibutuhkan untuk bekal hidup di masa akan datang.

Pengaruh dari hal tersebut terjadi pergeseran pengertian kurikulum yang awalnya sebagai sejumlah mata pelajaran berubah menjadi pengertian kurikulum sebagai pengalaman belajar peserta didik. Kurikulum adalah seluruh kegiatan yang dilakukan peserta didik baik di dalam maupun di luar sekolah asal kegiatan tersebut berada di bawah tanggung jawab guru/sekolah (Sanjaya; 2007:5). Perubahan pengertian kurikulum ini lebih jelas dikemukakan oleh Doll (1974:22) yang menyatakan :

"The commonly accepted definition of the curriculum has changed from content of courses of study and lists of subjects and courses to all the experiences which are offered to learners under the auspices or direction of the school".

Pendapat Doll tersebut menunjukkan adanya pergeseran pengertian kurikulum dari berorientasi pada isi menjadi berorientasi pada proses memperoleh pengalaman belajar dan sekaligus menjadi lebih luas dalam memaknai kurikulum. Dalam hal ini semua pengalaman belajar yang didapat peserta didik dibawah tanggung jawab sekolah adalah kurikulum.

Pendapat lain memandang kurikulum sebagai program atau rencana belajar dikemukakan oleh Taba (1962:11) bahwa:

"A curriculum is a plan for learning, therefore, what is known about the learning process and the development of the individual has bearing on shaping of a curriculum".

Demikian pula pendapat Oliva (1992:9) tentang kurikulum adalah sebagai berikut. "... curriculum is perceived as a plan or program for all the experiences which the learner encounters under the direction of the school. In practice, the curriculum consists of a number of plans, in written from and of varying scope, that deliniate the 
desired learning experiences. The curriculum, therefore, may be a unit, a course, a sequence of course, the school's entire program of studies - and may take place outside of class or school when directed by the personnel of the school".

Pendapat yang dikemukakan oleh dua ahli tersebut memandang kurikulum sebagai suatu rencana program belajar secara menyeluruh yang berisi semua pengalaman belajar, baik dalam bentuk unit, materi pelajaran, atau urutan materi pelajaran yang akan diberikan kepada peserta didik melalui proses di dalam atau diluar sekolah dan berada di bawah pengarahan sekolah.

Kedua pandangan ini sejalan dengan rumusan kurikulum menurut Undang-Undang Sisdiknas Nomor 20 Tahun 2003 yang mengatakan bahwa kurikulum adalah seperangkat rencana dan pengaturan mengenai isi dan bahan pelajaran serta cara yang digunakan sebagai pedoman penyelenggaraan kegiatan belajar mengajar. Batasan menurut Undang-Undang Sisdiknas dapat disimpulkan bahwa kurikulum selain sebagai rencana (as a plan) yang menjadi pedoman dalam proses pelaksanaan pembelajaran oleh guru, juga merupakan pengaturan isi dan cara pelaksanaan rencana. Keduanya berfungsi sebagai pedoman untuk mencapai tujuan pendidikan nasional.

\section{Ide Kurikulum 2013 PAUD}

Sebagaimana dijelaskan sebelumnya bahwa pemahaman tentang ide kurikulum merupakan komponen terpenting untuk dapat mengembangkan kurikulum, dengan demikian pengembangan KTSP Kurikulum 2013 yang harus dilakukan oleh tim pengembang KTSP jenjang PAUD perlu didasari pemahaman tentang ide kurikulum 2013 sebagaimana tercantum pada Permendikbud Nomor 146 Tahun 2014. Sejalan dengan pendapat Yani (2014:186) bahwa ide kurikulum setidaknya ada empat asas gagasan, yaitu asas filosofis, psikologi, sosiologis, dan organisatoris. Sedangkan menurut pendapat Hasan (2008:121) bahwa ide kurikulum adalah sebagai berikut.

Ide kurikulum merupakan rumusan dari posisi filosofis pendidikan yang dianut, pandangan teoritik tentang konsep kurikulum, model kurikulum yang digunakan, konsep tentang konten, organisasi kurikulum, desain kurikulum, desain dokumen kurikulum, posisi peserta didik dalam belajar.

Dari pendapat tersebut sesuai dengan pendapat Seller dan Miller bahwa tahap pengembangan kurikulum diawali dengan "orientation" (1985:4). Dalam penjelasan berikutnya dikemukakan bahwa "orientation" merupakan keyakinan yang mendasar tentang konsep pendidikan maupun kurikulum dan apa yang seharusnya dikerjakan oleh tim pengembang untuk mengembangkan kurikulum serta bagaimana peserta didik harus mengalami proses belajar. Pada fase ini setiap sudut pandang tentang tujuan pendidikan, konsep terhadap peserta didik, konsep tentang belajar, konsep tentang lingkungan belajar, konsep tentang peran guru, serta konsep tentang bagaimana belajar. Dua pendapat tersebut dapat dikatakan bahwa baik istilah ide maupun "orientation" merupakan posisi pemahaman terhadap ide kurikulum.

Berdasarkan dua pendapat tersebut menurut pemikiran penulis, ide kurikulum 2013 PAUD sangat penting dipahami oleh kepala sekolah dan guru yang berperan penting sebagai tim pengembang kurikulum, karena mereka merupakan ujung tombak dalam mengembangkan KTSP. Tujuan pendidikan, konsep terhadap peserta didik, konsep tentang belajar, konsep tentang lingkungan belajar, konsep tentang peran guru, serta konsep tentang bagaimana belajar, pada dasarnya telah termuat dalam landasan yuridis Kurikulum 2013 PAUD, baik secara eksplisit maupun implisit. 
Ide kurikulum 2013 PAUD dapat dipahami berdasarkan landasan yuridis yang telah ditetapkan sebagai berikut.

a. Peraturan Presiden Nomor 60 Tahun 2013 tentang Pengembangan Anak Usia Dini Holistik Integratif.

b. Peraturan Menteri Pendidikan dan Kebudayaan Nomor 137 Tahun 2014 tentang Standar Nasional PAUD.

c. Peraturan Menteri Pendidikan dan Kebudayaan Nomor 146 Tahun 2014 tentang Kurikulum 2013 PAUD.

Berdasarkan peraturan tersebut dapat diidentifikasi ide kurikulum 2013 PAUD dari sudut pandang posisi filosofis pendidikan, tujuan pendidikan dan tujuan kurikulum, konsep kurikulum, konsep belajar dan lingkungan belajar, konsep peserta didik dan peran guru, konten kurikulum, desain kurikulum. Secara rinci ide kurikulum 2013 PAUD dapat dijelaskan sebagai berikut.

\section{a. Posisi Filosofis Pendidikan}

Dalam lampiran Keputusan Mendikbud Nomor 146 Tahun 2014 (hal 3) tercantum ungkapan-ungkapan yang secara implisit dapat dimaknai sebagai posisi filosofis kurikulum 2013 PAUD. Ungkapan-ungkapan dikutip sebagai berikut.

Pendidikan berakar pada budaya bangsa untuk membangun kehidupan bangsa masa kini dan masa mendatang. Pandangan ini menjadikan Kurikulum 2013 Pendidikan Anak Usia Dini dikembangkan berdasarkan budaya bangsa Indonesia yang beragam dengan prinsip Bhinneka Tunggal Ika, sehingga pendidikan diarahkan untuk membangun kehidupan masa kini, dan untuk membangun dasar bagi kehidupan bangsa yang lebih baik di masa depan.

Pernyataan di atas secara tersirat dapat dipahami adanya dua hal sebagai ciri pandangan filosofis, yakni pendidikan sebagai transfer budaya dan pendidikan mempersiapkan manusia untuk hidup. Pandangan ini adalah pandangan filsafat esensialisme. Education's purpose, according to essentialist theory, is to prepare people for life (Power, 1982 dalam Sadulloh; 2015:163). Ide pandangan esensialisme tercermin pula dalam ungkapan sebagai berikut.

Anak adalah pewaris budaya bangsa yang kreatif. Menurut pandangan filosofi ini, prestasi bangsa di berbagai bidang kehidupan di masa lampau adalah sesuatu yang harus termuat dalam isi kurikulum untuk memberi inspirasi dan rasa bangga pada anak.

Ungkapan tersebut selain menunjukkan ciri ide filosofi esensialisme juga perenialisme, dengan pandangan bahwa pendidikan adalah upaya pewarisan budaya (Hasan; 2017:1). Namun demikian ungkapan 'membangun kehidupan masa kini untuk membangun kehidupan bangsa lebih baik di masa depan' merupakan ide filosofi progresivisme. Selain itu tercantum pula kalimat lain pada paragraph berikutnya yang berbunyi:

...mengembangkan kemampuan sebagai pewaris budaya bangsa yang kreatif dan peduli terhadap permasalahan masyarakat dan bangsa.

Dalam proses pendidikan, anak usia dini membutuhkan keteladanan, motivasi, pengayoman/perlindungan, dan pengawasan secara berkesinambungan sebagaimana dicontohkan oleh Ki Hajar Dewantara dalam filosofi: ing ngarso sung tulodo, ing madya mangun karso, tut wuri handayani. 
Ungkapan tersebut menunjukkan orientasi pandangan filosofi rekonstruksi sosial. Pada paragraph berikutnya dikemukakan bahwa usia dini adalah masa ketika anak menghabiskan sebagian besar waktu untuk bermain. Karenanya pembelajaran pada PAUD dilaksanakan melalui bermain dan kegiatan-kegiatan yang mengandung prinsip bermain. Ungkapan terakhir ini dapat dikatakan filosofi humanisme juga menjadi landasan kurikulum 2013 PAUD, karena pandangan humanisme pendidikan merupakan suatu upaya untuk menciptakan situasi yang permisif, rileks, akrab (Sukmadinata; 1999:87).

Dengan demikian posisi filosofis kurikulum 2013 PAUD tidaklah secara ekstrem atau mutlak menganut satu pandangan filosofis, tetapi lebih mengadaptasi beberapa pandangan filosofis yang dipertimbangkan sebagai yang terbaik untuk membentuk manusia Indonesia.

\section{b. Tujuan Pendidikan dan Tujuan Kurikulum}

Sebagaimana tercantum dalam Undang-undang Nomor 20 Tahun 2003 bahwa pendidikan di Indonesia bertujuan untuk berkembangnya potensi peserta didik agar menjadi manusia yang beriman dan bertakwa kepada Tuhan Yang Maha Esa, berakhlak mulia, sehat, berilmu, cakap, kreatif, mandiri, dan menjadi warga negara yang demokratis serta bertanggung jawab. Adapun tujuan kurikulum 2013 PAUD sebagaimana tercantum pada lampiran Permendikbud Nomor 146 Tahun 2014, yaitu bertujuan untuk mendorong berkembangnya potensi anak agar memiliki kesiapan untuk menempuh pendidikan selanjutnya.

Pernyataan tujuan tersebut menggambarkan bahwa tujuan pendidikan lebih menjaga keseimbangan manusia sebagai individu yang memiliki potensi, dan potensi yang dimiliki tersebut dikembangkan melalui proses pendidikan. Hal ini sejalan dengan posisi filosofis sebagaimana dijelaskan sebelumnya, bahwa filosofi humanisme menjadi salah satu landasan pendidikan. Selain itu mengembangkan potensi peserta didik menjadi manusia beriman, bertakwa, berakhlak mulia, sehat berilmu, cakap, kreatif, mandiri, dan menjadi warga Negara yang demokratis dan bertanggung jawab merupakan perpaduan dari filosofi esensialime, perenialisme, progresivisme, dan rekonstruksi sosial.

\section{c. Konsep Kurikulum}

Untuk dapat memahami konsep kurikulum 2013 PAUD dapat dipelajari dari karakteristik krikulum yang tercantum dalam Lampiran 1 Peraturan Mendikbud Nomor 146 Tahun 2014 sebagai berikut.

1) Mengoptimalkan perkembangan anak yang meliputi: aspek nilai agama dan moral, fisik-motorik, kognitif, bahasa, sosial emosional, dan seni yang tercermin dalam keseimbangan kompetensi sikap, pengetahun, dan keterampilan.

2) Menggunakan pembelajaran tematik dengan pendekatan saintifik dalam pemberian rangsangan pendidikan.

3) Menggunakan penilaian autentik dalam memantau perkembangan anak; dan

4) Memberdayakan peran orang tua dalam proses pembelajaran.

\section{d. Konsep Belajar dan Lingkungan Belajar}

Amanat yang tertuang dalam Undang-undang Nomor 20 Tahun 2003 bahwa pendidikan jenjang PAUD harus dipersiapkan secara terencana dan bersifat holistik sebagai dasar anak memasuki pendidikan lebih lanjut. Masa usia dini adalah masa emas perkembangan anak dimana semua aspek perkembangan dapat dengan mudah distimulasi. Periode emas ini hanya berlangsung satu kali sepanjang rentang kehidupan manusia. Oleh 
karena itu, pada masa usia dini perlu dilakukan upaya pengembangan menyeluruh yang melibatkan aspek pengasuhan, kesehatan, pendidikan, dan perlindungan.

Dalam landasan psikologis pedagogis Kurikulum 2013 PAUD dikemukakan bahwa pendidikan dikembangkan dengan mengacu pada cara mendidik anak sebagai individu yang unik, memiliki kecepatan perkembangan yang berbeda, dan belum mencapai masa operasional konkret, dan karenanya digunakan pendekatan pembelajaran yang sesuai dengan tahapan perkembangan dan potensi setiap anak. Berdasarkan pada apa yang tercantum dalam Undang-undang Nomor 20 Tahun 2003 dan landasan psikologis pedagogis tersebut dapat dikatakan bahwa konsep belajar anak usia PAUD berorientasi pada konsep psikologi humanistik dan konsep Gestalt. Hal ini tercermin dalam proses belajar menghargai keunikan individu dan tahap perkembangan peserta didik.

Psikologi humanisme berasumsi bahwa siswa atau peserta didik adalah yang pertama dan utama dalam pendidikan. Peserta didik memiliki potensi, kemampuan, dan kekuatan untuk berkembang. Getalt berpandangan bahwa individu merupakan satu kesatuan yang menyeluruh, pendidikan membina individu secara utuh, bukan hanya segi fisik dan intelektual tetapi juga segi sosial dan afektif (emosi, sikap, perasaan, dan nilai). Lingkungan belajar diciptakan sedemikian rupa agar permisif, rileks, dan akrab dalam suasana bermain (Sukmadinata; 1999:86-87).

Pandangan psikologi tersebut sejalan dengan apa yang tercantum dalam landasan teoritis Kurikulum 2013 PAUD, sebagaimana dikemukakan sebagai berikut.

Kurikulum berbasis kompetensi dirancang untuk memberikan pengalaman belajar seluas-luasnya bagi anak untuk mengembangkan kemampuan yang berupa sikap, pengetahuan, dan keterampilan yang direfleksikan dalam kebiasaan berpikir dan bertindak.

Kurikulum 2013 Pendidikan Anak Usia Dini menerapkan pembelajaran dalam bentuk pemberian pengalaman belajar langsung kepada anak yang dirancang sesuai dengan latar belakang, karakteristik, dan usia anak.

\section{e. Konsep Peserta Didik dan Peran Guru}

Konsep peserta didik diperankan sebaga subyek pendidikan, atau yang pertama dan utama, sebagaimana dijelaskan sebelumnya. Walupun secara eksplisit tidak tercantum seperti apa peran guru dalam pembelajaran, namun dengan konsep mengutamakan peserta didik dalam proses pendidikan, dapat dimaknai bahwa peran guru adalah fasilitator atau seorang yang memfasilitasi agar terjadi proses belajar melalui penciptaan lingkungan belajar yang permisif, rileks, dan bersahabat dan akrab.

\section{f. Konten Kurikulum}

Konten Kurikulum 2013 PAUD ditetapkan pula dalam Permendikbud Nomor 146 Tahun 2014 sebagaimana tercantum dalam Lampiran 1 yang merupakan bagian tak terpisahkan dari Peraturan tersebut. Konten Kurikulum 2013 PAUD berisi programprogram pengembangan, hal ini sesuai dengan konsep pendidikan jenjang PAUD. Program pengembangan meliputi enam program pengembangan, yaitu:

1) Program pengembangan nilai agama dan moral mencakup perwujudan suasana belajar untuk berkembangnya perilaku baik yang bersumber dari nilai agama dan moral serta bersumber dari kehidupan bermasyarakat dalam konteks bermain.

2) Program pengembangan fisik-motorik mencakup perwujudan suasana untuk berkembangnya kematangan kinestetik dalam konteks bermain. 
3) Program pengembangan kognitif mencakup perwujudan suasana untuk berkembangnya kematangan proses berpikir dalam konteks bermain.

4) Program pengembangan bahasa mencakup perwujudan suasana untuk berkembangnya kematangan bahasa dalam konteks bermain.

5) Program pengembangan sosial-emosional mencakup perwujudan suasana untuk berkembangnya kepekaan, sikap, dan keterampilan sosial serta kematangan emosi dalam konteks bermain.

6) Program pengembangan seni mencakup perwujudan suasana untuk berkembangnya eksplorasi, ekspresi, dan apresiasi seni dalam konteks bermain.

Selain dari enam program pengembangan tersebut, muatan Kurikulum 2013 PAUD ditetapkan adanya kompetensi yang harus dicapai oleh peserta didik, yakni terdiri dari Kompetensi Inti (KI) dan Kompetensi Dasar (KD). Kompetensi Inti merupakan gambaran pencapaian Standar Tingkat Pencapaian Perkembangan Anak pada akhir layanan PAUD usia 6 (enam) tahun. Sedangkan Kompetensi Dasar merupakan tingkat kemampuan dalam konteks muatan pembelajaran, tema pembelajaran, dan pengalaman belajar yang mengacu pada Kompetensi Inti. Kompetensi Inti mencakup sebagai berikut.

1) Kompetensi Inti 1 (KI-1) untuk kompetensi inti sikap spiritual.

2) Kompetensi Inti 2 (KI-2) untuk kompetensi inti sikap sosial.

3) Kompeyensi Inti 3 (KI-3) untuk kompetensi inti pengetahuan.

4) Kompetensi Inti 4 (KI-4) untuk kompetensi inti keterampilan.

Adapun rumusan Kompetensi Dasar dikembangkan dengan memperhatikan karakteristik dan kemampuan awal anak serta tujuan setiap program pengembangan. Kompetensi Dasar dibagi menjadi empat kelompok sesuai dengan pengelompokkan kompetensi inti yaitu:

1) Kelompok 1: kelompok Kompetensi Dasar sikap spiritual dalam rangka menjabarkan KI-1;

2) Kelompok 2: kelompok Kompetensi Dasar sikap sosial dalam rangka menjabarkan KI-2;

3) Kelompok 3: kelompok Kompetensi Dasar pengetahuan dalam rangka menjabarkan KI-3; dan

4) Kelompok 4: kelompok Kompetensi Dasar keterampilan dalam rangka menjabarkan KI- 4.

Rumusan Kompetensi Dasar secara rinci dapat dilihat pada Lampiran 1 Permendikbud Nomor 146 Tahun 2014.

\section{g. Desain Kurikulum}

Untuk dapat memahami desain Kurikulum 2013 PAUD dapat ditinjau dari posisi filosofis yang melandasi kurikulum. Dalam penjelasan sebelumnya telah diuraikan bahwa posisi filosofis Kurikulum 2013 PAUD mengadaptasi pandangan filsafat esensialisme, perenialisme, progresivisme, social recontructivism, dan humanisme. Pengaruh dari pandangan yang diadaptasi tersebut maka model desain Kurikulum 2013 PAUD juga tidak terfokus pada satu desain.

Apabila ditinjau dari desain Kurikulum 2013 PAUD terdapat metode yang digagas berorientasi pada pendekatan Saintifik. Organisasi isi kurikulum unified atau concentrated curriculum. Unified atau concentrated curriculum adalah pola organisasi bahan pelajaran yang tersusun tema-tema pelajaran dan didalam tema tersebut mencakup materi dari berbagai bahan disiplin ilmu, hal ini terlihat dari Kurikulum 2013 PAUD berbasis tema pembelajaran.

Pengaruh dari esensialisme dan perenialisme terhadap Kurikulum 2013 PAUD terdapat pada karakteristik desain kurikulum berbasis kompetensi (KBK). Desain KBK 
termasuk kurikulum teknologis, isi kurikulum diarahkan pada penguasaan kompetensi, sehingga kurikulum teknologi disebut juga kurikulum berbasis kompetensi. Karakteristik KBK juga dapat ditinjau dari tujuan, metode, organisasi bahan ajar, dan evaluasi. Tujuan pendidikan kurikulum ini diarahkan pada penguasaan kompetensi yang dirumuskan dalam bentuk perilaku, perbuatan atau kecakapan dan keterampilan yang dapat diamati dan diukur. Metode pembelajaran bersifat individual, tiap peserta didik diberikan serentetan tugas yang harus diselesaikan dan maju sesuai kecepatan masing-masing, atau disebut dengan mastery learning. Organisasi bahan ajar atau isi kurikulum diambil dari disiplin ilmu, tetapi diramu sedemikian rupa sehingga mendukung penguasaan kompetensi. Adapun evaluasi kegiatannya dilakukan pada setiap saat, pada proses maupun akhir pelajaran, akhir suatu unit atau semester, atau disebut dengan penilaian otentik. Fungsi evaluasi bervariasi, sebagai umpan balik bagi peserta didik dalam penguasaan kompetensi setelah akhir pembelajaran, suatu unit, atau semester, dan dapat juga menjadi umpan balik bagi guru dan pengembang kurikulum untuk penyempurnaan kurikulum.

Selain memiliki karakteristik desain kurikulum subyek akademik dan KBK, Kurikulum 2013 PAUD dilandasi filosofi social reconstructivism, dan dapat dikatakan memiliki karakteristik kurikulum rekonstruksi sosial. Karakteristik dari kurikulum rekonstruksi sosial dilihat dari komponen tujuan, metode, organisasi, dan evaluasi. McNeil (1990:31) mengemukakan:

The primary purpose of social reconstructionist is to confront the learner with the many severe problems that humankind faces. Social recontructionist believe that these problems are not the exclusive concern of "social studies" but of every discipline, including economics, aesthetics, chemistry, and mathematics.

Isi kurikulum adalah situasi nyata yang dihadapkan kepada peserta didik dan dikenalkan dengan situasi ideal agar peserta didik dapat menciptakan model-model situasi yang akan datang. McNeil berpendapat bahwa ada tiga kriteria untuk menseleksi bahan ajar (1990:32), yaitu harus nyata, melakukan kegiatan, dan berisi nilai. Dalam hal ini pengalaman belajar peserta didik diarahkan pada: 1) memfokuskan terhadap upaya perubahan masyarakat; 2) bekerjasama dengan masyarakat untuk mempelajari isu-isu masalah sosial dan mencari solusi; 3) melibatkan aspek emosi untuk mengidentifikasi masalah yang benar dan salah.

Adapun metode yang diterapkan adalah diskusi kelompok, latihan-latihan, kunjungan atau survei. Metode pembelajaran rekonstruksi sosial mencari keselarasan antara tujuantujuan nasional dengan tujuan peserta didik. Pola organisasi kurikulum disusun seperti sebuah roda yang di tengah-tengahnya sebagai poros dipilih suatu masalah yang akan menjadi tema utama dan akan dikaji melalui pembelajaran.

Aliran yang yang sejalan dengan social reconstructivism adalah pragmatisme. Pandangan pragmatisme bahwa dalam perencanaan kurikulum orang tua dan masyarakat dilibatkan untuk dapat memadukan sumber-sumber pendidikan formal dengan sumber sosial, politik, ekonomi, guna memperbaiki kondisi kehidupan (Nasution; 2011:25). Karakteristik ini teridentifikasi dari pengembangan KTSP yang harus melibatkan komite sekolah sebagai wakil orang tua siswa dan masyarakat. Progresivisme dapat dikatakan juga mewarnai desain Kurikulum 2013 PAUD, hal ini terlihat dari child centered sebagai kebijakan dalam pola pembelajaran. Pragmatisme dan progresivisme juga social constructivism memiliki pandangan yang mendekati sama dalam orientasi fungsi sekolah dan pembelajaran, yaitu child centered dan fungsi sekolah sebagai lembaga sosial.

Desain kurikulum humanistik juga mewarnai Kurikulum 2013 PAUD. Model kurikulum humanistik berpangkal pada aliran pendidikan pribadi (personalized education) yang menekankan pengembangan kepribadian individu secara utuh dengan pembelajaran 
berpusat pada peserta didik. Landasan filosofis dari aliran ini adalah progresivisme (John Dewey) dan romantisme (J.J. Rousseau). Asumsi dari aliran ini adalah anak atau peserta didik adalah yang pertama dan utama dalam pendidikan, dan merupakan subjek yang menjadi pusat kegiatan pendidikan.

Kurikulum 2013 PAUD disebut memiliki desain kurikulum humanistik teridentifikasi dari tujuan, metode, organisasi isi, dan evaluasi. Tujuan pendidikan adalah proses perkembangan pribadi yang dinamis yang diarahkan pada pertumbuhan, integritas, otonomi kepribadian, sikap yang sehat terhadap diri sendiri, orang lain, dan belajar. Tujuan pendidikan lebih terarah pada pembentukan individu teraktualisasi (self actualizing person). Organisasi isi dalam kurikulum menekankan integrasi, yaitu integrasi perilaku bukan saja yang bersifat intelektual tetapi juga emosional dan tindakan sehingga kurikulum berisi pengalaman yang menyeluruh. Hal ini terlihat dalam desain Kurikulum 2013 PAUD bahwa kompetensi yang dikembangkan mencakup kompetensi sikap, pengetahuan, dan keterampilan.

Metode yang diterapkan lebih mengarahkan peserta didik memperoleh pengalaman belajar, melalui cooperative learning, sosiodrama, kerja lapangan, kerja kelompok. Evaluasi model kurikulum humanistik lebih mengutamakan proses daripada hasil. Sasaran evaluasi adalah perkembangan anak untuk menjadi manusia yang mandiri.

\section{Pengembangan KTSP}

Sebagaimana dijelaskan dalam Buku Pedoman Penyusunan KTSP- PAUD bahwa penyusunan KTSP harus mengikuti prinsip-prinsip penyusunan KTSP. Prinsip penyusunan KTSP-PAUD pada dasarnya mengacu pada landasan filosofis, psikologis dan pedagogis, serta karakteristik Kurikulum 2013 PAUD. Secara berurutan meliputi 10 prinsip sebagai berikut.

a. Berpusat pada anak dengan mempertimbangkan potensi, bakat, minat, perkembangan, dan kebutuhan anak, termasuk kebutuhan khusus.

b. Kurikulum dikembangkan secara Kontekstual.

c. Mencakup semua dimensi kompetensi dan program pengembangan.

d. Program pengembangan sebagai dasar pembentukan kepribadian anak.

e. Memperhatikan tingkat perkembangan anak.

f. Mempertimbangkan cara anak belajar.

g. Holistik - integrative.

h. Belajar melalui bermain.

i. Memberi pengalaman belajar.

j. Memperhatikan dan melestarikan karakteristik sosial budaya.

Dalam mengembangkan KTSP PAUD ditetapkan prosedur operasional penyusunan, meliputi langkah-langkah sebagai berikut.

a. Analisis Konteks, dengan langkah sebagai berikut.

1) Satuan PAUD membentuk Tim Pengembang Kurikulum Satuan PAUD.

2) Tim Pengembang Kurikulum melakukan analisis kontek dengan mempelajari berbagai dokumen perundangan, kondisi, peluang, dan tantangan yang terkait dengan pendidik, sarana, prasarana, biaya, dan nilai-nilai yang mendasari, serta program yang akan dilakukan.

\section{b. Penyusunan Dokumen KTSP PAUD}

1) Tim Pengembang Kurikulum Satuan PAUD menyusun draft kurikulum dengan memperhatikan hasil analisis konteks di tahap sebelumnya.

2) Pembahasan draft kurikulum oleh semua Tim Pengembang untuk menelaah kembali kesesuaian kurikulum dengan perundangan dan tujuan lembaga. 
3) Tim Pengembang melakukan review dengan memperhatikan masukan dan perbaikan-perbaikan.

4) Satuan PAUD/ Yayasan menetapkan kurikulum Satuan PAUD.

5) Sosialisasi Kurikulum kepada seluruh guru, tenaga kependidikan, komite satuan PAUD/Komite orang tua.

\section{c. Pengesahan Dokumen KTSP}

1) Kepala Satuan PAUD mengajukan Kurikulum Tingkat Satuan PAUD yang sudah ditetapkan oleh Satuan PAUD/Ketua Yayasan ke Dinas Pendidikan Kabupaten untuk disyahkan atau setidaknya diketahui.

2) Dinas Pendidikan dalam hal ini pejabat yang ditunjuk sesuai dengan kewenangannya menyetujui dokumen kurikulum untuk dapat diterapkan di satuan PAUD yang bersangkutan.

3) Kepala Satuan PAUD/Pengelola menerapkan dan mengawasi pelaksanaan kurikulum dalam setiap kegiatan pembelajaran yang dilaksanakan di satuan PAUD tersebut.

Dokumen KTSP PAUD dikembangkan dalam dua jenis dokumen, yaitu Dokumen I disebut juga dokumen induk. Dokumen I berisi Visi, Misi,Tujuan,Karakteristik Kurikulum, Program Pengembangan dan Muatan Pembelajaran dan Kalender Pendidikan yang berisi Program Tahunan yang diterapkan di Satuan PAUD. Dokumen II disebut juga dokumen program yang berisi Program Semester (Prosem), Rencana Pelaksanaan Pembelajaran Mingguan (RPPM), Rencana Pelaksanaan Pembelajaran Harian (RPPH), dan Penilaian perkembangan anak. Lampiran dalam KTSP terdiri dari Kalender Pendidikan, Standar Operasional Prosedur (SOP), dan Tata Tertib Satuan Pendidikan.

Outline Dokumen KTSP secara garis besar sebagaimana ditetapkan dalam Pedoman Penyusunan KTSP PAUD sebagai berikut.

Halaman Judul

Kata Pengantar

Lembar Pengesahan

Daftar Isi

BAGIAN I PROFIL LEMBAGAA

A. Sejarah singkat Satuan lembaga PAUD

B. Struktur Kepengurusan Satuan Lembaga PAUD (penyelenggara, pengelola dan guru dan Uraian Tugas)

C. Alamat Dan Peta Lokasi Satuan lembaga PAUD

D. Status Satuan lembaga PAUD (negeri/swasta, izin operasional, akreditasi, dll).

\section{BAGIAN II DOKUMEN I}

A. Pendahuluan

1. Latar Belakang

2. Dasar Operasional Penyusunan KTSP PAUD

3. Tujuan Penyusunan KTSP PAUD

B. Visi, Misi, dan Tujuan

1. Visi Satuan PAUD

2. Misi Satuan PAUD

3. Tujuan Satuan PAUD

C. Karakteristik

D. Program Pengembangan dan Muatan Pembelajaran

E. Kalender Pendidikan dan Program Tahunan 
F. Standar Operasional Prosedur

BAGIAN III DOKUMEN II

A. Program Semester

B. Rencana Pelaksanaan Program Mingguan

C. Rencana Pelaksanaan Program Harian

D. Penilaian Perkembangan Anak

BAGIAN IV PENUTUP

BAGIAN V LAMPIRAN

1. Kalender Pendidikan dan Program Tahunan

2. Program Semester

3. Rencana Pelaksanaan Pembelajaran Mingguan (RPPM)

4. Rencana Pelaksanaan Pembelajaran Harian (RPPH)

5. Penilaian Perkembangan Anak

6. Standar Operasional Prosedur (SOP) Layanan Anak

7. dll (yang dianggap perlu)

\section{Implikasi Ide Kurikulum 2013 PAUD dalam Dokumen KTSP}

Sebagaimana dijelaskan sebelumnya bahwa ide kurikulum merupakan komponen penting dalam mengembangkan KTSP, maka ide tersebut akan mewarnai dokumen yang dihasilkan, yaitu dokumen KTSP PAUD. Implikasi ide kurikulum dapat terlihat dalam Dokumen I maupun Dokumen II.

Posisi filosofis akan berimplikasi terhadap rumusan visi misi serta tujuan Satuan PAUD. Muatan Kurikulum akan berimplikasi terhadap substansi program pengembangan dan muatan pembelajaran. Apabila tim pengembang memahami posisi filosofis, landasan teori kurikulum serta landasan psikologis pedagogis PAUD maka substansi program pengembangan dan muatan kurikulum dikemas dalam pengembangan yang berorientasi pada landasan filosofis, psikologis dan pedagogis yang tertuang dalam Kurikulum 2013 PAUD.

Perumusan SOP yang dikembangkan akan berpihak pada kepentingan peserta didik, dan tentu saja melibatkan peran orang tua dalam pembelajaran. SOP dikembangkan bermuara pada pelayanan peserta didik sejak kedatangan di Satuan PAUD, proses bermain dan pembelajaran, sampai dengan berakhirnya kegiatan belajar.

Konsep belajar dan perkembangan anak usia dini berimplikasi pada penyusunan Rencana Pelaksanaan Pembelajaran Harian (RPPH), Rencana Pelaksanaan Pembelajaran Mingguan (RPPM) dan rancangan penilaian perkembangan anak. Tanpa memahami konsep belajar dan perkembangan anak maka RPPH. RPPM, dan rancangan penilaian perkembangan akan tersusun sebagaimana kebiasaan lama yang ditempuh guru.

Implikasi ide kurikulum dalam dokumen KTSP harus secara jelas dan eksplisit dituangkan sesuai ide esensial dari Kurikulum 2013 PAUD. Apabila dokumen KTSP yang dikembangkan oleh tim pengembang KTSP tidak merupakan cerminan dari ide kurikulum, maka dapat dikatakan terjadi perbedaan antara ide esensial dan dokumen KTSP yang disusun oleh Tim Pengembang. Atau dapat dikatakan terdapat dua jenis kurikulum yang berbeda, yaitu kurikulum sebagai ide dan kurikulum sebagai dokumen KTSP. Hal ini dapat dikatakan pula bahwa dokumen KTSP bukanlah suatu siklus kesinambungan antara ide kurikulum dengan dokumen kurikulum, tetapi masing-masing berdiri sendiri dan berbeda antara ide kurikulum dan dokumen kurikulum.

Perlu disadari bahwa dokumen KTSP merupakan dokumen rencana yang akan dilaksanakan dalam proses pembelajaran, sehingga apabila antara ide dan dokumen tidak terjadi kesinambungan maka akan terjadi ketidaksinambungan pula pada pelaksanaan atau 
kurikulum sebagai proses. Dampak yang dikhawatirkan adalah, jika proses pembelajaran adalah sesuatu yang berbeda dengan apa yang direncanakan dalam dokumen kurikulum maka terdapat dua kurikulum yang berbeda yaitu kurikulum sebagai rencana tertulis dan kurikulum sebagai proses. Dalam keadaan yang demikian maka kurikulum sebagai proses bukanlah implementasi dari kurikulum sebagai rencana yang tercantum dalam dokumen kurikulum. Dengan demikian maka hasil belajar adalah hasil kurikulum sebagai proses dan bukan hasil dari kurikulum yang direncanakan dan bukan implementasi dari ide kurikulum.

\section{PENUTUP}

Ide kurikulum merupakan komponen penting yang harus dipahami oleh tim pengembang kurikulum, pemahaman terhadap ide kurikulum akan sangat membantu tim pengembang dalam menyusun dokumen KTSP. Tanpa memahami terlebih dahulu ide Kurikulum 2013 PAUD maka dokumen KTSP PAUD yang disusun oleh tim pengembang akan berbeda dengan ide esensial yang ditetapkan dalam Kurikulum 2013 PAUD. Adanya perbedaan antara ide kurikulum dengan dokumen KTSP sebagai dokumen rencana, akan berdampak pula pada proses pembelajaran. Apabila terjadi perbedaan yang demikian, maka antara ide kurikulum, dokumen KTSP, dan proses pembelajaran sebagai "curriculum in action" menjadi tiga hal yang berbeda dan tidak ada kesinambungan sebagai suatu pengembangan kurikulum tingkat satuan pendidikan.

Oleh karena itu posisi kepala sekolah dan guru yang merupakan ujung tombak pengembangan KTSP memiliki peran penting sebagai tim pengembang kurikulum tingkat satuan pendidikan. Komitmen Tim sangat dibutuhkan, karena tanpa komitmen akan terjadi kelambanan. Kelambanan tim dalam pemikiran dan usaha mewujudkan KTSP akan menghambat implementasi kurikulum. Kelambanan terjadi apabila guru-guru atau tim pengembang yang terbentuk merasa lebih aman dengan praktik-praktik rutin yang sudah dilaksanakan tanpa ada kemamuan untuk menerima dan mencoba hal-hal baru yang memerlukan pemikiran dan usaha, termasuk perubahan pada diri guru dalam kesiapan menerima konsep-konsep baru tentang Kurikulum 2013 PAUD.

\section{DAFTAR PUSTAKA}

Doll, R.C. (1976). Curriculum Improvement Decision Making and Process. New York: Allyn and Bacon, Inc.

Hasan, S.H. (1988). Evaluasi Kurikulum. Jakarta: Departemen Pendidikan dan Kebudayaan, Direktorat Jenderal Pendidikan Tinggi.

. (2008). Evaluasi Kurikulum. Bandung: Kerjasama PT Rosda dan UPI Bandung.

Mc Neil, J. D. (1977). Curriculum: Comprehensive Introduction (4 ${ }^{\text {th }}$ ed.). London: Scott, Foresman, \& Brown.

Nasution, S. (2011). Asas-asas Kurikulum. Jakarta: Bumi Aksara.

Oliva, P.F. (1992). Developing the Curriculum.(Third Edition). New York. Harper Collins Publishers Inc.

Rosyada, Dede. (2007). Paradigma Pendidikan Demokratis: Sebuah Model Pelibatan Masyarakat dalam Penyelenggaraan Pendidikan. Jakarta: Kencana.

Sadullah, U. (2015). Pengantar Filsafat Pendidikan. Bandung: Alfabeta.

Sanjaya, W. (2008). Kurikulum dan Pembeajaran, Teori dan Praktik Pengembangan Kurikulum Tingkat Satuan Pendidikan (KTSP). Jakarta: Kencana Predana Media Group.

Sukmadinata. N. S. (1997). Pengembangan Kurikulum Teori dan Praktek. Bandung: Rosdakarya. (2007). Metode Penelitian Pendidikan. Bandung: Rosdakarya. 
Sukmadinata, N.S. dan Syaodih, E. (2012). Kurikulum \& Pembelajaran Kompetensi. Bandung: Refika Editama.

Yamin, M. (2012). Panduan Manajemen Mutu Kurikulum Pendidikan, Panduan Lengkap Tata Kelola Kurikulum Efektif. Yogyakarta:DIVA Press.

Yani, Ahmad. (2013). Mindset Kurikulum 2013. Bandung: Alfabeta.

Zais, Robert S. (1976). Curriculum Principles and Foundations. New York:Harper \& Row Publisher.

\section{Sumber Online:}

Braslavsky, C. (2013). Definition of The Concept of Curriculum. [Online]. Tersedia: http://www.ibe.unesco.org. [27 September 2013]

Hasan, S. Hamid. (2017). Konferensi Nasional Sejarah. [Online]. Tersedia: https://www.geocities.ws [online 12 Desember 2017].

\section{Pedoman, Peraturan, dan Perundang-undangan:}

Departemen Pendidikan Nasional. Undang-Undang Nomor 20 Tahun 2003 tentang Sistem Pendidikan Nasional. Jakarta: Depdiknas.

(2016). Peraturan Presiden Republik Indonesia Nomor 60 Tahun 2013 tentang

Pengembangan Anak Usia Dini Holistik Integratif. Jakarta:Kemdikbud. . (2016). Peraturan Menteri Pendidikan dan Kebudayaan Nomor 137 Tahun 2014 tentang Standar Nasional PAUD. Jakarta: Kemdikbud.

. (2014). Peraturan Menteri Pendidikan dan Kebudayaan Nomor 146 Tahun 2014 tentang Kurikulum 2013 Pendidikan Anak Usia Dini. Jakarta: Kemdikbud. 